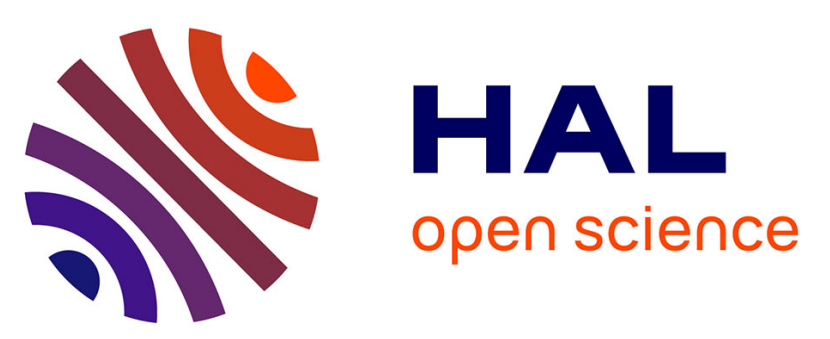

\title{
Investigations on the aetiology of pinching off syndrome in four white-tailed sea eagles (Haliaeetus albicilla) from Germany
}

\author{
Kerstin Müller, Elvira Schettler, Helga Gerlach, Leo Brunnberg, Hafez \\ Mohamed Hafez, Kim Hattermann, Reimar Johne, Rainer Kollmann, Oliver \\ Krone, Michael Lierz, et al.
}

\section{To cite this version:}

Kerstin Müller, Elvira Schettler, Helga Gerlach, Leo Brunnberg, Hafez Mohamed Hafez, et al.. Investigations on the aetiology of pinching off syndrome in four white-tailed sea eagles (Haliaeetus albicilla) from Germany. Avian Pathology, 2007, 36 (03), pp.235-243. 10.1080/03079450701338748 . hal-00540078

\section{HAL Id: hal-00540078 https://hal.science/hal-00540078}

Submitted on 26 Nov 2010

HAL is a multi-disciplinary open access archive for the deposit and dissemination of scientific research documents, whether they are published or not. The documents may come from teaching and research institutions in France or abroad, or from public or private research centers.
L'archive ouverte pluridisciplinaire HAL, est destinée au dépôt et à la diffusion de documents scientifiques de niveau recherche, publiés ou non, émanant des établissements d'enseignement et de recherche français ou étrangers, des laboratoires publics ou privés. 


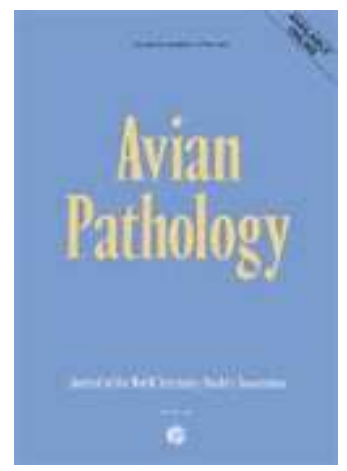

\section{Investigations on the aetiology of pinching off syndrome in four white-tailed sea eagles (Haliaeetus albicilla) from Germany}

\begin{tabular}{|c|c|}
\hline Journal: & Avian Pathology \\
\hline Manuscript ID: & CAVP-2006-0115.R2 \\
\hline Manuscript Type: & Original Research Paper \\
\hline $\begin{array}{r}\text { Date Submitted by the } \\
\text { Author: }\end{array}$ & 23-Jan-2007 \\
\hline Complete List of Authors: & $\begin{array}{l}\text { Müller, Kerstin; Small Animal Clinic, Free University of Berlin } \\
\text { Schettler, Elvira; Leibniz Institute for Zoo and Wildlife Research; } \\
\text { Wildlife Park Eekholt } \\
\text { Gerlach, Helga } \\
\text { Brunnberg, Leo; Small Animal Clinic, Free University of Berlin } \\
\text { Hafez, Hafez; Institute for Poultry Diseases, Free University of } \\
\text { Berlin } \\
\text { Hattermann, Kim; Robert Koch Institute } \\
\text { Johne, Reimar; Institute for Virology, Faculty of Veterinary } \\
\text { Medicine, University of Leipzig } \\
\text { Kollmann, Rainer; Project Group for the Protection of the White- } \\
\text { tailed Sea Eagle } \\
\text { Krone, Oliver; Leibniz Institute for Zoo and Wildlife Research } \\
\text { Lierz, Michael; Institute for Poultry Diseases, Free University of } \\
\text { Berlin } \\
\text { Linke, Sonja; Robert Koch Institute } \\
\text { Lüschow, Dörte; Institute for Poultry Diseases, Free University of } \\
\text { Berlin } \\
\text { Mankertz, Anette; Robert Koch Institute } \\
\text { Müller, Hermann; Institute for Virology, Faculty of Veterinary } \\
\text { Medicine, University of Leipzig } \\
\text { Prusas, Christina; Institute for Poultry Diseases, Free University of } \\
\text { Berlin } \\
\text { Raue, Rüdiger; Institute for Virology, Faculty of Veterinary } \\
\text { Medicine, University of Leipzig } \\
\text { Soike, Dirk; Landesamt für Verbraucherschutz und Landwirtschaft }\end{array}$ \\
\hline
\end{tabular}


Speck, Stephanie; Leibniz Institute for Zoo and Wildlife Research Wolf, Petra; Department of Animal Nutrition, University of Veterinary Medicine Hannover

Frölich, Kai; Leibniz Institute for Zoo and Wildlife Research

Keywords:

birds of prey, white-tailed sea eagles, pinching off syndrome, feather abnormality

\section{SCHOLARONE \\ Manuscripts}


Investigations on the aetiology of pinching off syndrome in four white-tailed sea eagles (Haliaeetus albicilla) from Germany

Kerstin Müller ${ }^{1 * * * *}$, Elvira Schettler ${ }^{2,3 * *}$, Helga Gerlach ${ }^{4}$, Leo Brunnberg ${ }^{1}$, Hafez Mohamed Hafez ${ }^{5}, K_{\text {Kim Hattermann }}^{6}$, Reimar Johne ${ }^{7}$, Rainer Kollmann ${ }^{8}$, Oliver Krone ${ }^{2}$, Michael Lierz ${ }^{5}$, Sonja Linke ${ }^{6}$, Dörte Lueschow ${ }^{5}$, Annette Mankertz ${ }^{6}$, Hermann Müller ${ }^{7}$, Christina Prusas ${ }^{5}$, Rüdiger Raue ${ }^{7}$, Dirk Soike ${ }^{9}$, Stephanie Speck $^{2}$, Petra Wolf ${ }^{10}$ and Kai Frölich ${ }^{2}$

${ }^{1}$ Small Animal Clinic, Free University of Berlin, Oertzenweg 19b, 14163 Berlin, Germany, ${ }^{2}$ Leibniz Institute for Zoo and Wildlife Research, Alfred-Kowalke-Str. 17, 10315 Berlin, Germany, ${ }^{3}$ Wildlife Park Eekholt, 24623 Großenaspe, Germany, ${ }^{4}$ Grosshesseloherstr. 23, 81479 München, Germany, ${ }^{5}$ Institute for Poultry Diseases, Free University of Berlin, Königsweg 63, 14163 Berlin, Germany, ${ }^{6}$ Robert Koch Institute, Nordufer 20, 13353 Berlin, Germany, ${ }^{7}$ Institute for Virology, Faculty of Veterinary Medicine, University of Leipzig, An den Tierkliniken 29, 04103 Leipzig, Germany, ${ }^{8}$ Project Group for the Protection of the White-tailed Sea Eagle, Olshausenstraße 40, 24118 Kiel, Schleswig-Holstein, Germany, ${ }^{9}$ Landesamt für Verbraucherschutz und Landwirtschaft, Pappelallee 20, 14469 Potsdam, and ${ }^{10}$ Department of Animal Nutrition, University of Veterinary Medicine Hannover, Bischofsholer Damm 15, 30173 Hannover, Germany
Formatted: Section start Continuous

Formatted: Footer 
*To whom correspondence should be addressed. Tel: 00493083862388 . Fax: 004930 83862521. E-mail: Muellerkerstin@gmx.de

***First two authors contributed equally to this publication. 
Abstract

The purpose of this study was to investigate the aetiology of the pinching off syndrome (POS), a generalised feather abnormality affecting free-living fledglings of the whitetailed sea eagle (Haliaeetus albicilla) (WTSE) in Europe. For the first time, extensive clinical, haematological, biochemical, virological, bacteriological, nutritional, histopathological, parasitological and electron microscopical examinations were performed on three females and one male suffering from POS. Early and increased cytokeratin formation at the base of regenerating feathers and their follicle was observed in affected birds. Ultrathin sections of the feather papillae revealed an extended stratum transitivum and a compact, thickened keratinised stratum corneum. The transitional cells in POS feathers contained vacuoles often associated with the nucleus. Lipofuscin accumulations in neurons, glial cells and islet cells of the pancreas were found in all examined birds. It was not clear if there is an association between the occurrence of lipofuscin and POS.

No evidence was found to suggest that infectious agents (parasites, bacteria, fungi or viruses), malnutrition or hormonal imbalances are involved in the aetiology of POS in WTSEs. It remains unclear whether there is a genetic background of POS. 
Key words

birds of prey, feather abnormality, feather loss, feather dystrophy, pinching off syndrome, white-tailed sea eagles, Haliaeetus albicilla

Introduction

Due to intense human persecution the German population of the white-tailed sea eagle (WTSE) was believed to consist of only 20 breeding pairs at the beginning of the $20^{\text {th }}$ century (Hauff 2004). The population increased slowly after the species was protected but decreased again between 1950 and 1970 due to environmental contamination with DDT (Hauff 1998). The numbers remained relatively constant until the end of the seventies. Between 1970 and 1980 the German population of WTSEs consisted of approximately 100 breeding pairs (Hauff 2004). At this time (1975) the first case of a generalised feather abnormality was found in a WTSE fledgling from SchleswigHolstein, Germany (Rüger 1981). From 1975 to 2006, a total of 17 fledglings of freeliving WTSEs with a feather abnormality (pinching off syndrome, POS) were found near their nesting sites in Germany. In Europe, altogether 32 cases are documented during that period (Müller, et al. in press).

At the time of capture all primaries, secondaries and rectrices of affected WTSEs were malformed, and many feathers were already lost. The coverts were involved to various degrees. No affected bird was able to fly. Some birds were kept in captivity for several years but feather quality continued to worsen.

Formatted: Footer 
A wide variety of reasons for generalised skin and feather abnormalities in birds are known, including parasitic, bacterial, fungal and viral infections, trauma, chemical or toxic substances, inadequate nutrition, genetic, neoplastic, immune-mediated diseases, allergy or irradiation, behavioural disorders (Cooper \& Harrison 1994) as well as hormonal imbalances (Oglesbee 1992). The cause of POS is unknown and no therapy is available to date. The aim of the present study of four birds with POS was to investigate the aetiology of POS and to describe the clinical appearance, the pathology and histopathology of feathers and organs of affected birds.

Materials and Methods

Animals. The study was conducted between 2001 and 2004 on four German WTSEs found in the wild with generalised feather abnormalities. The investigated birds were from three different German federal states Schleswig-Holstein (SA01), Brandenburg (SA02; SA03) and Saxony-Anhalt (SA93) (Table 1). The three females and one male were recently fledged at the time of capture. They were found on the ground near their nests in the months July $(n=2)$ and August $(n=2)$. At the time of the first clinical investigations three WTSEs were fledglings (SA01, SA02, SA03) and approximately 15 to 20 weeks old. The fourth bird (SA93), already 10 years old, was found in 1993 and kept in captivity until 2003. SA01 was observed during the nestling period and showed visible alterations of the flight feathers by the age of 10 weeks. The feather condition was clinically evaluated different times in SA01 and SA02, and the birds were kept for 31 and 17 months, respectively. SA03 was kept for only two months. 
In all birds the primaries, secondaries and rectrices were either lost or malformed; hence all birds were never able to fly.

Clinical examination and laboratory tests. Initial diagnostic procedures included evaluation of the feather status and lateral and ventrodorsal radiographs of the whole body. Endoscopy of the coelom was conducted in SA01 and SA02 some days after admission using routine methods (Taylor 1994). Growing abnormal primary and secondary feathers, and rectrices were obtained under isoflurane inhalation anaesthesia from three birds (SA01, SA02, SA03). Blood samples for virological examination, haematology, biochemistry and heavy metal analysis were obtained from the Vena ulnaris. Haematocrit was determined with the microhaematocrit method and haemoglobin was measured spectrophotometrically using the cyanmethaemoglobin method. Analysis of blood chemistry was carried out on lithium heparin plasma immediately after blood sampling by Konelab $30 ®$ (Thermo Electron GmbH, Dreieich, Germany) at $37^{\circ} \mathrm{C}$ and included potassium, sodium, total calcium, anorganic phosphorus, alanine aminotransferase (ALT), aspartate aminotransferase (AST), glutamate dehydrogenase (GLDH), lactate dehydrogenase (LDH), glucose, urea, uric acid, alkaline phosphatase (AP), creatine kinase (CK), total protein (TP, biuret method), and cholinesterase. Albumin was measured via electrophoresis. Blood lead levels were measured by atomic absorption spectrometry in a federal laboratory (Federal Environmental Agency Berlin, Germany).

For investigation of thyroid gland function, a TSH-stimulation test was conducted in all four birds and one control bird without feather abnormalities. After blood sampling for baseline plasma thyroxine level, 1IU thyroid-stimulating-hormone (TSH, Sigma-Aldrich 


\section{re-}

Chemie GmbH, Munich, Germany) was injected in the Musculus supracoracoideus and a second blood sample was taken six hours later. Plasma was separated and stored at $20^{\circ} \mathrm{C}$. Radioimmunoassay analysis was performed in a commercial laboratory.

Pathology and parasitology. All four WTSEs were euthanised, because the feather quality deteriorated and release into the wild was not possible. The birds were measured and weighed prior to dissection. Detailed pathological techniques including the assessment of the body condition have been described previously (Krone, et al. 2003). Postmortem examination concentrated on signs of specific diseases, organ alterations, parasites and specific alterations of feathers and skin. For histopathology, formalin fixed samples of the heart, liver, lungs, airsacs, kidneys, spleen, ovary or testes, oviduct, proventriculus, ventriculus, duodenum, jejunum, different parts of the brain (cerebrum, cerebellum), thyroid glands, parathyroid glands, pancreas, adrenal glands, bursa cloacalis, thymus, large blood vessels and growing feathers (primaries, secondaries and rectrices) were embedded in paraffin and cut at $3 \mu \mathrm{m}$. Standard stains included haematoxylin and eosin (HE), periodic acid-Schiff reaction (PAS), and Turnbull blue (TB).

Tissue samples from growing feathers from biopsies and samples collected from euthanised birds (primaries, secondaries and rectrices) including the feather follicles as well as various organs were stored in $\mathbf{7 \%}$ formalin for histopathology, in cold modified Karnowsky medium and $3 \%$ glutaraldehyde for electron microscopy and at $-\mathbf{2 0}{ }^{\circ} \mathrm{C}$ and $80^{\circ} \mathrm{C}$ for negative staining.

Growing contour feathers still containing pulp of all birds were examined for quill mites by standard methods (Clayton \& Wather 1997). 
Electron microscopy. In search of an infectious aetiology of POS negative staining for electron microscopy was performed. Tissue homogenates of the bursa cloacalis, spleen, liver, skin, thymus, intestinal mucosa, caecal tonsils, brain and feather follicle were diluted 1:5 in PBS, sonicated for $40 \mathrm{~s}$ at $20 \mathrm{kHz}$ and clarified for $15 \mathrm{~min}$ at $3000 \mathrm{~g}$. Supernatant was used for direct preparation and particle enrichment. For particle enrichment the supernatant was centrifuged $12 \mathrm{~min}$ at $120,000 \mathrm{~g}$ directly on the microscopic grid using an air-driven ultracentrifuge (Beckman Airfuge, Global Medical Instrumentation, Ramsey, USA). Specimens were stained with $2 \%$ phosphotungstic acid (PTA).

Tissue samples of the bursa cloacalis, spleen, liver and caecal tonsils of one juvenile bird (SA03) with POS were prepared for ultrastructural analysis according to standard procedure: glutardialdehyde-fixation, osmium tetroxide postfixation, dehydration, epoxy resin embedding, staining with uranyl acetat and lead citrate. Specimens were examined with a Jeol JEM 1010 electron microscope at $80 \mathrm{kV}$.

For fine structural analysis basal parts $(2-3 \mathrm{~mm}$ in diameter) of growing primaries and secondaries of two WTSEs with POS (SA01, SA03) and one control bird without feather abnormalities were prepared. Chemical fixation, dehydration and embedding of specimens for light- and electron microscopy were performed according to Elias \& Friends (1975) and Pfeiffer et al. (2000). Areas of cross sectioned basal parts of regenerating feathers and its follicles were preselected in the light microscope using semithin sections $(60-70 \mathrm{~nm})$. Fine structural analysis was performed in the stratum germinativum of the epidermal collar and the follicle wall (terminology as described by 
Lucas \& Stettenheim, 1972). Ultrathin sections were examined with a Philips CM 10 electron microscope.

Bacteriology. Sterile 0.9 mm cotton swabs (Hain Diagnostika, Nehren, Germany) were used to take samples from feather follicles and feather pulp of five primaries of every bird, collected aseptically during feather biopsies and necropsies. Swabs were stored in transport medium (Hain Diagnostika) and kept at room temperature up to 5 hours until plated onto Columbia agar (5\% sheep blood), Chocolate agar, Gassner medium, Sabouraud agar and MacConkey II agar (Oxoid, Wesel, Germany). All agar plates were incubated aerobically at $37^{\circ} \mathrm{C}$ for $24-72 \mathrm{~h}$; Columbia agar and Chocolate agar plates in $5 \% \mathrm{CO}_{2}$ (AnaeroJar 2.5l, Oxoid). In addition, Sabouraud agar plates were incubated at room temperature. Swabs were also cultured for 24 hours in trypticase soy broth for enrichment and then subcultured only if the enrichment broth appeared cloudy. Primary identification of microbial isolates was based on Gram staining, cellular morphology, catalase and oxidase reaction. Commercially available analytical profile index (API) from bioMérieux (Nürtingen, Germany) were applied for the identification of staphylococci and micrococci (API Staph), streptococci (API 20 Strep), coryneform bacteria (API Coryne), and gram-negative nonfermenting bacteria (API 20 NE). Conventional biochemical tests (Bisping \& Amtsberg 1988; Quinn, et al. 2000) were also used.

Virus cultivation. Liver, lung, spleen, bursa cloacalis homogenates and cloacal swabs were inoculated on primary chicken embryo liver cell monolayer (CEL), prepared from 11 day old specified pathogen free embryonated chicken eggs (Valo, Lohmann Tierzucht 
GmbH, Germany). Tissue samples from liver, spleen, feather follicle, and buffy coat were used to inoculate confluent monolayers of chicken embryo fibroblast (CEF). Inoculated cell cultures were incubated at $37^{\circ} \mathrm{C}$ and examined daily for cytopathic effect (CPE) for 5-7days. Three blind passages were carried out for each sample before it was judged to be negative for virus propagation.

Polymerase chain reactions (PCRs). DNA for reticuloendotheliosis virus detection (REV) was extracted from tissue, buffy coat and from the 3rd passage of CEF cell suspension by the QIAamp® DNA Mini Kit (Qiagen GmbH, Hilden Germany). Two different primer pairs were chosen for detection of REV proviral DNA amplifying a 291 bp fragment of the REV long terminal repeat (LTR) region (Aly, et al. 1993; Diallo, et al. 1998) and a 642 bp fragment of the envelope gene (Singh, et al. 2000) respectively. The presence of DNA of avian polyomavirus (APV), beak and feather disease virus (BFDV) and pigeon circovirus (PiCV) was investigated using DNA isolated from EDTA blood, feather follicle tissue, spleen, kidney, liver, heart, skin, bursa cloacalis, thymus, intestinal mucosa, and the caecal tonsil of all birds by PCR as described by Johne \& Müller (1998), Raue et al. (2004) and Raue et al. (2005), respectively. These PCRs were performed with DNA isolated from the samples using the DNeasy Tissue Kit (Qiagen, Hilden, Germany) and Taq DNA polymerase (PeqLab, Germany). Additionally, for circovirus consensus PCR, capable of detecting different avian circoviruses (Todd et al., 2001), DNA was prepared from EDTA blood and feather follicle tissue (Qiagen DNeasy tissue kit; Qiagen, Hilden/Germany). Initially, samples were tested in a control PCR (Hattermann, et al. 2004), then circovirus consensus PCR was performed according to Todd et al. (2001).

Formatted: Footer 
All PCRs were controlled by the use of a negative control reaction to which no sample-DNA was added. y Plasmids containing the specific PCR products were used as positive controls. PCR products were separated on ethidium bromide-stained agarose gels and visualised by UV transillumination.

Serology. Antibodies against West Nile virus (WNV) were detected using two different methods. For the neutralisation test plasma samples were diluted in Dulbecco's modified eagle medium (DMEM) and $25 \mu \mathrm{L}$, which had been mixed with the same volume of a virus suspension WNV genotype 1 containing $50 \mathrm{TCID50} / \mathrm{mL}$, were added to a 96-well microtiter plate and the mixture was incubated for 2 hours at $37^{\circ} \mathrm{C}$. Vero cells $(104$ cells in $100 \mu \mathrm{L}$ medium) were added to each well and incubated for 3 days at $37^{\circ} \mathrm{C}$. All specimens were initially tested in duplicate at a dilution of 1:10. Reactive samples were retested at dilutions of 1:10-1:320.

Immunofluorescence test was conducted for detection of IgG plasma antibodies against WNV. Commercially available immunofluorescence test slides (EUROIMMUN AG, Lübeck, Germany) coated with WNV-infected cells and a commercial antibird FITC labelled antibody (Bethyl, Inc., Montgomery, Texas, U.S.) were used. Following the manufacturer's protocol, the diluted plasma (1:10, 1:50) was incubated with the cells for $30 \mathrm{~min}$. The slides were washed, the conjugate was added and they were incubated again for $30 \mathrm{~min}$. After a second washing step the biochips were embedded and the slides were analysed under a fluorescence microscope. 
Determination of amino acid levels in feathers and plasma. Feather contents of at least two removed or shed deformed primaries or secondaries of the four WTSEs with POS and three feathers of a WTSE without feather abnormalities were analysed. After washing the feathers with acetone they were dried and ground. Amino acids were analysed after oxidation to determine levels of cystine and methionine and after

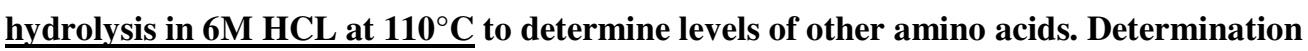
of the individual amino acids for feathers and plasma was carried out by ionic exchanger chromatography (amino acids analyzer, model LC 3000, Biotronic, Berlin, Germany) using different time zone elutions of individual amino acids with different buffers. Afterwards measurements of the several tapes were done photometrically by a colour reaction with ninhydrine.

Determination of trace elements in feathers and plasma. To estimate levels of the trace elements copper and zinc, ground feathers were mixed with $20 \mathrm{ml}$ nitric acid (HNO3, $65 \%)$ and $1 \mathrm{ml}$ hydrogen peroxide $\left(\mathrm{H}_{2} \mathrm{O}_{2}, 30 \%\right)$ and dissolved by microwave acid digestion in a high performance rotor (mls 1200 mega, Milestone, Sorisole, Italy). A „high performance rotor“ (HPR-1000/6, Milestone, Sorisole, Italy) was utilised to pulverise feathers. Hereby organic matter of feathers is destroyed and the residues comprise among others the inorganic trace elements copper and zinc. These elements in feathers and plasma were detected by atomic absorption spectrometry (Unicam solaar 969, Unicam, Cambridge, United Kingdom).

Results 
Clinical examination. At the first clinical presentation all birds were infested with feather lice. In SA01, a few quill mites belonging to the Family Ascouracaridae (Gaud \& Atyeo 1976) were detected once in the calamus of a lost feather. Treatment with ivermectin (Ivomec ${ }^{\circledR}, 0.4 \mathrm{mg} / \mathrm{kg}$ i.m. once a week over three weeks) eliminated the mites, but caused no improvement in feather quality.

All birds had wounds on one or both wings medial of the carpal joint caused by mechanical irritation through wing flapping. Pruritus was not observed.

In bird SA93 a slight body shivering were observed at all times. Radiographs and endoscopy revealed no significant alterations. The feather condition deteriorated during the time of captivity in all birds.

Apart from this and the feather abnormalities no other clinical findings could be observed.

Description of the feather abnormalities. All WTSEs were unable to fly. The appearance of the syndrome differed slightly between all four birds. Main characteristics of the flight and tail feathers were as follows: Feather loss and malformation (Figure 1)

Rachis contorted or/and ventral open, ventral deposits of keratin (Figure 2)

Vane flabby and curved ventrally (Figure 2)

Calamus scaly and shortened (Figure 2)

Proximal umbilicus constricted, irregular, with feather sheath remains

Feather length normal to extremely shortened (Figure 2, 3). 
The coverts were modified in all but one bird (SA01) with ventral scaly rachis and reduced quantity (Figure 1). The new developing feathers were extremely short and abnormal in appearance (Figure 3). The feather quality worsened over time. In birds kept in captivity for years (SA01 31 months, SA02 17 months, SA93 10 years,) no moulting period were observed, the birds lost and replaced their feathers continuously. Blood analysis. The blood chemistry and haematology values were similar to those of healthy nestlings (Müller, unpublished). Blood lead and mercury levels ranged between 0.013-0.045 ppm and 0.001-0.250 ppm, respectively and are considered as background levels (Church, et al. 2006; Jagoe, et al. 2002). TSH stimulation test showed an evident increase of thyroxine $\left(\mathrm{T}_{4}\right)$ level (Table 2$)$.

Hi: . hology of the feathers. 52 primaries, secondaries and rectrices of all four WTSEs with POS were histologically examined (SA93 n=18; SA01 n=3; SA02 n=9; SA03 n=22). Although various numbers of feathers were investigated per bird the proportion of feathers altered as described below did not differ between three individuals (SA93, SA02, SA03). Only three suitable feathers could be examined from SA01. In these feathers some alterations were not diagnosed, but this is most probably contributeddue to the low number of examined feathers. In 27 feathers $(51.9 \%$ of feathers examined, $\mathrm{n}=4$ birds) deposits of keratin were observed in the papilla between the epithelium of the feather follicle and the epithelium of the pulp. In the pulp epithelium dyskeratosis (23.1\%, 12 feathers in 3 birds) and degeneration associated with vacuoles in the cytoplasm as well as necrosis were diagnosed $(40.4 \%, n=3$ birds). In $32.7 \%$ of the investigated feathers ( $n=4$ birds) degeneration and necrosis of the epithelia appeared in
Comment [M1]: As lead is never normal in living organisms, low lead levels are called background levels. This is the valid term used in studies dealing with heavy metal intoxications in birds. (E.g., Church et al. 2006) 
the epidermal collar and the papilla. The epithelia, which accompanied the developing feathers, were modified in a similar way. The epithelium of the feather sheath was altered due to degeneration and necrosis $(17.3 \%$ of feathers, $n=3$ birds $)$ as well as dyskeratosis (19.2\% of feathers, $n=4$ birds).

The epithelium of the feather follicle was affected to a lesser extent: in $11.5 \%(\mathrm{n}=\mathbf{2}$ birds) degeneration and necrosis, in $\mathbf{1 1 . 5 \%}(\mathrm{n}=\mathbf{2}$ birds) dyskeratosis. Pathological proliferation was mainly observed at the pulp epithelium $(19.2 \%, \mathrm{n}=3 \mathrm{birds})$.

Due to alterations of the epithelium in the pulp and feather sheath also the development of the ramogenic columns and in consequentially vane formation was impaired. A change of the growth direction of the rami $(13.5 \%, n=3$ birds) was leading to a disordered appearance of the vanes. Damage to keratin formation resulted in $\mathbf{1 3 . 5 \%}$ ( $n=3$ birds) in missing barbs or the rami consisted of few cell layers. In $23.1 \%(n=4$ birds) of feathers, premature keratinisation of the ramogenic column inhibited further growth (Figure 4). In $7.7 \%$ of the feathers ( $n=2$ birds), dyskeratosis in the ramogenic column was observed.

In $75 \%$ of the examined growing feathers ( $=4$ birds) a marked heterophil leucocytosis in the pulp was observed. The papilla and the epidermal collar were affected in $\mathbf{1 7 . 3 \%}$, but the epithelium of the feather sheath was affected in only $3.8 \%$. Leucocytes were not detected in the epithelium of the feather follicle.

Heterophil leucocytes were also visible between the ramogenic columns and the more proximally growing rami in $\mathbf{1 7 . 3 \%}$ of feathers ( $\mathrm{n}=3$ birds). In only one case high numbers of bacteria were detected between the rami. The bacteria were small and it was 
not possible to determine their morphology. Haemorrhages within the pulp were detected in $65.4 \%$ of the feathers ( $n=3$ birds).

Histopathology of the skin. Dyskeratosis was observed focally in the epidermis of all birds. Deposits of fibrin were detected in two birds. Proliferation of the stratum germinativum (n=1 bird, SA93) and degenerate nuclei ( $n=1$ bird, SA93) were, however, rare.

Other alterations of the skin were necrotising dermatitis ( $\mathrm{n}=1 \mathrm{bird}, \mathrm{SA93})$, perivascular inflammation ( $n=3$ birds), degeneration of the smooth muscles ( $n=3$ birds), hyaline degeneration ( $\mathrm{n=1}$ bird, SA93), subendothelial atherosclerosis-like deposits in dermal blood vessels as well as brightly stainable and enlarged nuclei infiltrating the walls of these vessels ( $n=1$ bird, SA93).

Histopathology of the organs. Lipofuscin was detected at varying levels in all birds (Table 3).

Ultrastructure. Differences within the fine structure of the germinative layer were found between the two POS birds and the healthy bird. In control feathers the stratum germinativum was well stratified - from pulp to follicle - by one layer of stratum basale and several layers of stratum intermedium and stratum transitivum. Only a thin keratinised outer layer (stratum corneum) was tightly attached to the thin stratum corneum of the follicle. In affected feathers, the cell layers of the stratum germinativum were less easily distinguishable. Main characteristics were an extended stratum transitivum and a compact, several microns thick keratinised layer representing the 
$\checkmark$

stratum corneum (Figure 5A). Cells of the stratum transitivum in affected feathers were connected by many desmosomes. Numerous bundles of cytokeratin filaments extended from the desmosomes throughout the cells (Figure 5B). The transitional cells contained vacuoles with dense inclusions often closely associated with the nucleus and small vesicles $(200-500 \mathrm{~nm})$ in the cytoplasm (Figure 5B). The outer membrane of the small vesicles in cross-sectional profiles often displayed a trilaminar structure with intramembrane particles. Such vesicles were not observed in control feathers. Incidentally, melanocytes with many melanosomes and cell extensions into the stratum transitivum were found in the stratum intermedium of one POS feather (SA03), but not in the other birds. The ultrastructural appearance corresponded well with the histopathological findings. Ultrastructurally, neither the feather papillae nor the examined organs showed any evidence of an infectious cause of POS. Negative contrast staining also failed to reveal an infectious agent in the growing feathers and in the organs of all birds.

Bacteriology. Moderate numbers of ten different bacteria were recovered from the feather follicle, feather pulp and the soft tissue around the feather follicle (Table 4). Most of the isolated bacteria belonged to the group of Gram-positive cocci and Grampositive coryneform rods. Two species comprised Gram-negative rods. The predominant genus found was Staphylococcus. Fungi were not detected in any of the samples.

Virology. All PCRs were negative for REV, APV, BFDV and PiCV. Also, the consensus PCR, which is capable of detecting a broad range of different circoviruses, was negative 
in all cases. In addition no virus was cultivated by passage in CEL. No antibodies against WNV were detected.

Trace elements and amino acids in feathers and blood plasma. No significant differences between control birds and POS birds were detected in the trace element and amino acid content of the analysed feathers and plasma.

Discussion

The four investigated birds belong to a group of free-living WTSEs that were found in Germany between 1975 and 2006 showing a generalised feather loss and feather malformation known as POS. Only nestlings of both sexes were affected.

Most case reports about feather abnormalities in birds of prey describe pinching off as a loss of one or a few abnormal premature primaries or rectrices (Cooper 1972; Glasier 1980; Grünhagen 1988; Mavrogordato 1960). Typical characteristics of the affected feathers are constricted calamus and pinched appearance (Cooper 1972; Glasier 1980; Grünhagen 1988). Diminished flying and hunting abilities were not described by those workers and a normal feather will regrow after some days (Glasier 1980; Grünhagen 1988; Mavrogordato 1960).

In the Netherlands, a generalised feather abnormality was reported in fledglings of the northern goshawk (Accipiter gentilis) (Bijlsma, et al. 1994; Ottens, et al. 1997; Van Geneijgen, et al. 1995; Vedder 2000). No investigations into the aetiology have been performed.

Formatted: Footer 
r-

In our study, extensive examinations of affected birds were conducted.

Quill mites (Syringophilidae) were reported to be associated with feather loss in birds of prey (Philips 2000). Quill mites of the Family Ascouracaridae were identified in one bird. However, feather abnormalities did not improve after treatment with ivermectin. No quill mite infestation in any of the other birds was observed. Quill mites are therefore not thought to be the main cause of POS in WTSEs.

Malley \& Whitbread (1996) reported that avian skin is fairly resistant to primary bacterial infection. In our study, only a limited number of bacteria commonly identified as normal skin flora in other animals were isolated. Gram-positive cocci predominated which is consistent with investigations regarding the normal bacterial flora in common buzzards (Buteo buteo) (Pérez, et al. 1994). Among the Gram-negative bacteria isolated were Acinetobacter species, which are typically detected in soil and water. Little is known, however, about their pathogenicity for wild animals (Quinn, et al. 2000). Escherichia coli was isolated from two birds but these are regarded as contamination because only a few bacteria were detected histopathologically in the feather papillae and only in one case. In contrast to reports about bacterial polyfolliculitis (Oglesbee \& Oglesbee 1994; Rosskopf, et al. 1983) our birds never revealed signs of pruritus nor feather follicle swelling as seen by Bayer et al. (1976).

Mycotic infections of feathers in pigeons and psittacine birds can lead to feather loss in several parts of the body especially at the breast. In some cases, pruritus and feather pulling were also observed (Gartrell, et al. 2005; Tudor 1983). Feather loss and hyperkeratotic short feathers were symptoms of fungal infections in Gouldian finches (Erythrura gouldiae) and Java sparrows (Padda oryzivora) (Pass 1989). Spores as well as hyphae were present in the keratinised layers (Pass 1989), but could not be detected in the birds of the present study.

Circovirus (Latimer, et al. 1991; Pass, et al. 1994; Raidal \& Riddoch 1997; Stewart, et al. 2006), polyomavirus (Bernier, et al. 1981, 1984), adenovirus (Cooper \& Harrison 1994), parvovirus (Cooper \& Harrison 1994; Jestin, et al. 1991), REV (Koyama, et al. 1975;

Formatted: Footer 
Koyama, et al. 1980; Tajima, et al. 1977) and WNV (P. Redig, personal communication) are known to cause generalised feather loss and/or feather malformation in various bird species. The PCR tests applied yielded no evidence that circoviruses, APV or REV are involved in the development of POS. Also, no viruses were detected by inoculation of the samples onto cultures of CEL cells. However, the possibility cannot be excluded that presently unknown viruses which could not be detected by the used PCR assays or which could not be propagated in CEL cells are involved in POS.

Several reports exist about feather abnormalities in undernourished poultry.

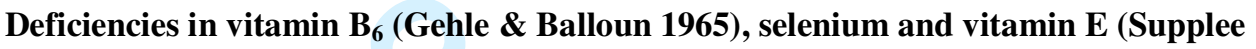
1966), zinc (Supplee, et al. 1961; Young, et al. 1958) and amino acids like arginine (Anderson \& Warnick 1967), glycine (Robel 1977), valin, leucine, isoleucine or phenylalanine and tyrosine (Anderson \& Warnick 1967; Robel 1977) are described. The present study, however, revealed no abnormalities of amino acid and trace element composition. Since the general physical condition in all birds was normal and stress marks were absent in affected remiges and rectrices, it therefore seems unlikely that malnutrition caused POS.

In poultry the oral intake of T-2 toxin produced by Fusarium spp. (Hoerr, et al. 1981; Wyatt, et al. 1975) may also cause feather alterations. In this case, however, it is unlikely that T-2 toxin was involved, because affected birds typically suffer a reduced growth rate (Wyatt, et al. 1975) and other organ lesions like gastroenteritis and hepatocellular degeneration occur (Mishra, et al. 1987). Such signs were not observed in the present study.

Hypothyroidism was associated with feather loss in a scarlet macaw (Ara macao)

(Oglesbee 1992). In all four WTSEs with POS, thyroxine basal levels were comparable 
r

with these of scarlet macaws $(1.72 \pm 0.66 \mathrm{nmol} / \mathrm{L})$ and African grey parrots (Psittacus erithacus) (1.83 $\pm 0.57 \mathrm{nmol} / \mathrm{L})$ (Lothrop, et al. 1985), but much lower than reported for pigeons (16.5-26.6 nmol/L) (Lumeij \& Westerhof 1988). An increase 5 to 13 times of thyroxine basal level was observed six or eight hours after TSH application, which is comparable to investigations in psittacine species by Lothrop et al. (1985) and pigeons by Lumeij \& Westerhof (1988). However, histopathology revealed a moderate follicle collapse and absence of colloid from follicles of the thyroid glands in three birds. Although it is not possible to explain this apparent discrepancy at present, hypothyroidism is considered unlikely to be the primary cause of POS in WTSEs since histopathological alterations were moderate, the thyroid glands could be adequately stimulated with TSH and no other organ alterations were found.

There was no histopathological indication that adrenal gland degeneration caused feather loss as described by Onderka and Claffey (1987) in a blue and gold macaw (Ara ararauna).

Some inherited feather abnormalities are known in poultry. Dysplastic remiges of chicken, that may follow an autosomal recessive genetic expression (Urrutia, et al. 1983), seem to be very similar to POS found in WTSEs. The WTSE population suffered two crises during the last 150 years caused by human persecution until the beginning of the 20th century and by a reduced breeding success due to the accumulation of DDT in the fifties, sixties and seventies (Hauff 1998). Inbreeding during these periods might have contributed to the appearance of POS.

This is the first description of histopathology and ultrastructure of POS in WTSEs and Formatted: Adjust space between Latin and Asian text, Adjust space between Asian text two major findings seem to be important. The early and increased cytokeratin and numbers

formation at the base of a regenerating feather and its follicle seems to interrupt the 
normal development leading to the altered appearance of the feather. Lipofuscin accumulation in neurons, glial cells and pancreas was found in all investigated birds. One of these birds (SA93, ten years old) had tremors. This might be associated with lipofuscin accumulation, since lipofuscin is known to cause degenerative neurological diseases in humans (Gray \& Woulfe 2005), horses (Hartley, et al. 1982), sheep (Jolly, et al. 1990), cattle (Bianchi 1979), dogs (Borras, et al. 1999), cats (Bildfell, et al. 1995; Green \& Little 1974) and was also reported in a nine-month old peach-faced love bird (Agapornis roseicollis) (Reece \& Macwhirter 1988). Lipofuscin is a lipoprotein that linearly accumulates intralysosomally in postmitotic cells, especially in neurons and cardiac myocytes. It is a degradation product of cell constituents and is considered to be a normal manifestation of aging (Porta 1991). Lipofuscin has been found in neurons of human infants at the age of four months (Porta 2002). It still remains unknown why lipofuscin is not completely degraded by the lysosomes (Porta 2002). The appearance of a comparatively high amount of lipofuscin especially in the two young WTSEs and whether there is an association between the occurrence of lipofuscin and POS needs further evaluation, although in the authors' view, the latter seems unlikely. In conclusion, our investigations have given no indication that infectious agents (parasites, bacteria, fungi or viruses), malnutrition or hormonal imbalances play a role in the aetiology of POS in WTSEs. Moreover, the clinical and histological examinations did not reveal that trauma, chemical or toxic substances, neoplasia or allergy were likely to be the cause of POS. Feather loss and malformation seem to be a consequence of increased and premature cytokeratin formation in the growing feather. It remains unclear whether there is a genetic background of POS. 
Acknowledgement

We would like to thank H. Pendl for performing the blood cell counts, S. Pfeiffer and M.

Beese for assistance with the ultrastructural examination of feather material and I.

Nehlmeier for help by testing for West Nile virus infection.. We also thank D. Haas, P.

Sömmer, H. Freymann and A. Valentin for their support and J. R. Philips as well as

Carol Ksiazek for their helpful comments.

This study was partly funded by the Brandenburg State Office for Environment and the German Nature Conservation Union (NABU), Section Berlin.

Formatted: Line spacing: single

Formatted: Indent: Left: $\mathbf{0}$ pt, First line: $\mathbf{0}$ pt

\section{References}


Aly, M.M., Smith, E.J. \& Fadly, A.M. (1993). Detection of reticuloendotheliosis virus infection using the polymerase chain reaction. Avian Pathology, 22, 543-554.

Anderson, J.O. \& Warnick, R.E. (1967). Gross abnormalities in chicks fed amino acid deficient diets. Poultry Science, 46, 856-862.

Bayer, R.C., Muir, F.V., Chawan, C.B. \& Bryan, T.A. (1976). Infected feather follicles in cage reared broilers. Poultry Science, 55, 1194-1200.

Bernier, G., Morin, M. \& Marsolais, G. (1981). A generalized inclusion body disease in the budgerigar (Melopsittacus undulatus) caused by a papovavirus-like agent. Avian Diseases, 25, 1083-1092.

Bernier, G., Morin, M. \& Marsolais, G. (1984). Papovavirus induced feather abnormalities and skin lesions in the budgerigar: clinical and pathological findings. Canadian Veterinary Journal, 25, 307-310.

Bianchi, M. (1979). Lipofuscine in the neurons of large herbivores during growth and old age. Atti del Convegno Nazionale Societa Italiana delle Scienze Veterinarie, 33, 137. Bijlsma, R.G., Speelman, R., Ottens, H.J., Hasper, H. \& van Manen, W. (1994). Een veerafwijking bij een nestjonge Havik Accipiter gentilis. De Takkeling, 2, 38-40.

Bildfell, R., Matwichuk, C., Mitchell, S. \& Ward, P. (1995). Neuronal ceroidlipofuscinosis in a cat. Veterinary Pathology, 32, 485-488.

Bisping, W. \& Amtsberg, G. (1988). Colour atlas for the diagnosis of bacterial pathogens in animals. Berlin, Hamburg: Paul Parey Scientific Publishers.

Borras, D., Ferrer, I. \& Pumarola, M. (1999). Age-related changes in the brain of the dog. Veterinary Pathology, 36, 202-211.

Church, M.E., Gwiazda, R., Risebrough, R.W., Sorenson, K., Chamberlain, C.P., Farry, S., Heinrich, W., Rideout, B.A. \& Smith, D.R. (2006). Ammunition is the principal 
source of lead accumulated by California condors re-introduced to the wild.

Environmental Science \& Technology, 40, 6143-6150.

Clayton, D.H. \& Wather, B.A. (1997). Collection and quantification of arthropod parasites of birds. In D.H. Clayton, \& J. Moore. (1997). Host-parasite evolution. General principles and avian models. (pp419-440). Oxford: Oxford University Press.

Cooper, J.E. (1972). Feather conditions in birds of prey. Journal of the North American Falconers' Association, 11, 39-44.

Cooper, J.E. \& Harrison, G.J. (1994). Dermatology. In B.W. Ritchie, G.J. Harrison, \& L.R. Harrison. (1994). Avian medicine: principles and application (pp607-639). Lake Worth, Florida: Wingers Publishing.

Diallo, I.S., MacKenzie, M.A., Spradbrow, P.B. \& Robinson, W.F. (1998). Field isolates of fowlpox virus contaminated with reticuloendotheliosis virus. Avian Pathology, 27, 6066.

Elias, P.M. \& Friends, D.S. (1975). The permeability barrier in mamalian epidermis. The Journal of Cell Biology, 65, 185-189.

Gartrell, B.D., Rogers, L. \& Alley, M.R. (2005). Eosinophilic dermatitis associated with Trichosporon asahii in a cockatiel (Nymphicus hollandicus). Journal of Avian Medicine and Surgery, 19, 25-29.

Gaud, J. \& Atyeo, W.T. (1976). Ascouracarinae, n. sub-fam. des Syringobiidae, sarcoptiformes plumicioles. Acarologia, 18, 143-162.

Gehle, M.H. \& Balloun, S.L. (1965). Selected hemocytological effects of vitamin B6 deficiency in chicks. The Journal of Nutrition, 87, 197-201.

Glasier, P. (1980). Moulting, imping and coping. London: BT Batsford.

Formatted: Footer 
Gray, D.A. \& Woulfe, J. (2005). Lipofuscin and aging: a matter of toxic waste. Sciences of Aging Knowledge Environment, 2005, re1.

Green, P.D. \& Little, P.B. (1974). Neuronal ceroid-lipofuscin storage in Siamese cats. Canadian Journal of Comparative Medicine, 38, 207-212.

Grünhagen, H. (1988). Federanomalien bei Greifvögeln. Greifvögel und Falknerei, 73-76. Hartley, W.J., Kuberski, T., LeGonidec, G. \& Daynes, P. (1982). The pathology of Gomen disease: a cerebellar disorder of horses in New Caledonia. Veterinary Pathology, 19, 399-405.

Hattermann, K., Maerz, A., Slanina, H., Schmitt, C. \& Mankertz, A. (2004). Assessing the risk potential of porcine circoviruses for xenotransplantation: consensus primerPCR-based search for a human circovirus. Xenotransplantation, 11, 547-50.

Hauff, P. (1998). Bestandsentwicklung des Seeadlers Haliaeetus albicilla in Deutschland seit 1980 mit Rückblick auf die vergangenen 100 Jahre. Vogelwelt, 119, 47-63.

Hauff, P. (2004). Seeadler (Haliaeetus albicilla). In K. Gedeon, A. Mitschke, \& C. Sudfeldt. (2004). Brutvögel in Deutschland (pp8-9). Hohenstein-Ernstthal: Stiftung Vogelmonitoring Deutschland.

Hoerr, F.J., Carlton, W.W. \& Yagen, B. (1981). Mycotoxicosis caused by a single dose of T-2 toxin or diacetoxyscirpenol in broiler chickens. Veterinary Pathology, 18, 652-664. Jagoe, C.H., Bryan, A.L., Jr., Brant, H.A., Murphy, T.M. \& Brisbin, I.L., Jr. (2002). Mercury in bald eagle nestlings from South Carolina, USA. Journal of Wildlife Diseases, $38,706-712$.

Jestin, V., Bras, M.O.l., Cherbonnel, M., Gall, G.l. \& Bennejean, G. (1991).

Demonstration of highly pathogenic parvovirus (Derzsy's disease virus) in flocks of muscovy ducks. Recueil de Medecine Veterinaire, 167, 849-857. 
Johne, R. \& Müller, H. (1998). Avian polyomavirus in wild birds: genome analysis of isolates from Falconiformes and Psittaciformes. Archives of Virology, 143, 1501-1512. Jolly, R.D., Martinus, R.D., Shimada, A., Fearnley, R.M. \& Palmer, D.N. (1990). Ovine ceroid-lipofuscinosis is a proteolipid proteinosis. Canadian Journal of Veterinary Research, 54, 15-21.

Koyama, H., Nagashima, T., Ohwada, Y. \& Saito, Y. (1975). Cause of "nakanuke" in chickens. II. Isolation of C-type virus from material infected with turkey herpesvirus. The Kitasato Archives of Experimental Medicine, 48, 93-105.

Koyama, H., Sasaki, T., Ohwada, Y. \& Saito, Y. (1980). The relationship between feathering abnormalities ("nakanuke") and tumour production in chickens inoculated with reticuloendotheliosis virus. Avian Pathology, 9, 331-340.

Krone, O., Langgemach, T., Sömmer, P. \& Kenntner, N. (2003). Causes of mortality in white-tailed sea eagles from Germany.In B. Helander, M. Marquiss, \& W. Bowerman (Eds). Proccedings of the Sea Eagle 2000 (pp211-218). Björkö, Sweden.

Latimer, K.S., Rakich, P.M., Niagro, F.D., Ritchie, B.W., Steffens, W.L., Compagnoli, R.P., Pesti, D.A. \& Lukert, P.D. (1991). An updated review of psittacine beak and feather disease. Journal of the Association of Avian Veterinarians, 5, 211-221.

Lothrop, C.D., Jr., Loomis, M.R. \& Olsen, J.H. (1985). Thyrotropin stimulation test for evaluation of thyroid function in psittacine birds. Journal of the American Veterinary Medical Association, 186, 47-48.

Lucas, A.M. \& Stettenheim, P.R. (1972). Avian Anatomy. Integument. Part II. Washington, D.C.: Gov. Print. Off.

Lumeij, J.T. \& Westerhof, I. (1988). Clinical evaluation of thyroid function in racing pigeons (Columba livia domestica). Avian Pathology, 17, 63-70. 
Malley, A.D. \& Whitbread, T.J. (1996). The integument. In P.H. Beynon, N. Forbes, \&

N.H. Harcourt-Brown. (1996). Manual of raptors, pigeons and waterfowl (pp129-139).

Cheltenham: British Small Animal Veterinary Association.

Mavrogordato, J.G. (1960). A hawk for the bush. London: HF \& G Witherby.

Mishra, U.K., Dwarkanath, P.K. \& Hossain, M.I. (1987). Clinical manifestation and hepatic trace minerals in growing chickens as influenced by T-2 toxin. Indian Journal of Animal Sciences, 57, 1069-1074.

Müller, K., Altenkamp, R., Brunnberg, L., Fašungová, L., Freymann, H., Frölich, K., Kollmann, R., Krone, O., Literák, I., Mizera, T., Sömmer, P. \& Schettler, E. (In press). Pinching off syndrome in free-living white-tailed sea eagles (Haliaeetus albicilla) from Europe - frequency and distribution of a generalized feather abnormality. Journal of Avian Medicine and Surgery, In press.

Oglesbee, B.L. (1992). Hypothyroidism in a scarlet macaw. Journal of the American Veterinary Medical Association, 201, 1599-1601.

Oglesbee, B.L. \& Oglesbee, M.J. (1994). Feather dystrophy in a cockatiel (Nymphicus hollandicus). Journal of the Association of Avian Veterinarians, 8, 16-20.

Onderka, D.K. \& Claffey, F.P. (1987). Adrenal degeneration associated with feather loss in a macaw. Canadian Veterinary Journal, 28, 193-194.

Ottens, H.J., Jansman, H. \& Speelman, R. (1997). Genetische afwijking hoogstwaarschijnlijk andermaal oorzaak van veerafwijking bij nestjonge Havik Accipiter gentilis. De Takkeling, 5, 12-16.

Pass, D.A. (1989). The pathology of the avian integument: a review. Avian Pathology, 18, 2-72.

Formatted: Footer 
Pass, D.A., Plant, S.L. \& Sexton, N. (1994). Natural infection of wild doves (Streptopelia senegalensis) with the virus of psittacine beak and feather disease. Australian Veterinary Journal, 71, 307-308.

Pérez, J.M., Extremera, A.L. \& Ruiz, I. (1994). Bacteriological study of the feathers and lice of captive common buzzards (Buteo buteo). Avian Pathology, 23, 163-168.

Pfeiffer, S., Vielhaber, G., Vietzke, J.-P., Wittern, K.-P., Hintze, U. \& Wepf, R. (2000). High-pressure freezing provides new information on human epidermis: simultaneous protein antigen and lamellar lipid structure preservation. Study on human epidermis by cryoimmobilization. The Journal of Investigative Dermatology, 114, 1030-1038.

Philips, J.R. (2000). A review and checklist of the parasitic mites (Acarina) of the Falconiformes and Strigiformes. Journal of Raptor Research, 34, 210-231.

Porta, E.A. (1991). Advances in age pigment research. Archives of Gerontology and Geriatrics, 12, 303-320.

Porta, E.A. (2002). Pigments in aging: an overview. Annals of the New York Academy of Sciences, 959, 57-65.

Quinn, P.J., Carter, M.E., Markey, B. \& Carter, G.R. (2000). Clinical Veterinary Microbiology. London: Mosby.

Raidal, S.R. \& Riddoch, P.A. (1997). A feather disease in senegal doves (Streptopelia senegalensis) morphologically similar to psittacine beak and feather disease. Avian Pathology, 26, 829-836.

Raue, R., Johne, R., Crosta, L., Bürkle, M., Gerlach, H. \& Müller, H. (2004). Nucleotide sequence analysis of a $\mathrm{C} 1$ gene fragment of psittacine beak and feather disease virus amplified by real-time polymerase chain reaction indicates a possible existence of genotypes. Avian Pathology, 33, 41-50. 
Raue, R., Schmidt, V., Freick, M., Reinhardt, B., Johne, R., Kamphausen, L., Kaleta, E.F., Müller, H. \& Krautwald-Junghanns, M.-E. (2005). A disease complex associated with pigeon circovirus infection, young pigeon disease syndrome. Avian Pathology, 34, 418-425.

Reece, R.L. \& MacWhirter, P. (1988). Neuronal ceroid lipofuscinosis in a lovebird. The Veterinary Record, 122, 187.

Robel, E.J. (1977). A feather abnormality in chicks fed diets deficient in certain amino acids. Poultry Science, 56, 1968-1971.

Rosskopf, W.J., Jr., Woerpel, R.W., Sievers, M.J. \& Pater, C. (1983). Treatment of feather folliculitis in a lovebird. Modern Veterinary Practice, 64, 923.

Rüger, A. (1981). Bestandsstützung durch Adoptionsverfahren - Erfahrungen mit Seeadlern in Schleswig-Holstein. Natur und Landschaft, 56, 133-135.

Singh, P., Kim, T.J. \& Tripathy, D.N. (2000). Re-emerging fowlpox: evaluation of isolates from vaccinated flocks. Avian Pathology, 29, 449-455.

Stewart, M.E., Perry, R. \& Raidal, S.R. (2006). Identification of a novel circovirus in Australian ravens (Corvus coronoides) with feather disease. Avian Pathology, 35, 86-92. Supplee, W.C. (1966). Feather abnormality in poults fed a diet deficient in vitamin E and selenium. Poultry Science, 45, 852-854.

Supplee, W.C., Creek, R.D., Combs, G.F. \& Blamberg, D.L. (1961). The zinc requirements of poults receiving pracitcal diets. Poultry Science, 40, 171-176.

Tajima, M., Nunoya, T. \& Otaki, Y. (1977). Pathogenesis of abnormal feathers in chickens inoculated with reticuloendotheliosis virus. Avian Diseases, 21, 77-89. 
Taylor, M. (1994). Endoscopic examination and biopsy techniques. In B.W. Ritchie, G.J.

Harrison, \& L.R. Harrison. (1994). Avian medicine: principles and application (pp327354). Lake Worth, Florida: Wingers Publishing.

Todd, D., Weston, J.H., Soike, D. \& Smyth, J.A. (2001). Genome sequence determinations and analyses of novel circoviruses from goose and pigeon. Virology, 286, 354-362.

Tudor, D.C. (1983). Mycotic infection of feathers as the cause of feather-pulling in pigeons \& psittacine birds. Veterinary Medicine, Small Animal Clinician, 78, 249-253. Urrutia, M.S., Crawford, R.D. \& Classen, H.L. (1983). Dysplastic remiges, a genetic abnormality reducing feathering in the domestic fowl. The Journal of Heredity, 74, 101104.

van Geneijgen, P., van Nie, G.J. \& de Smid, T. (1995). Veerafwijking bij nestjonge Havik. De Takkeling, 3, 91.

Vedder, O. (2000). Veerafwijking bij nestjonge Havik Accipiter gentilis, en mogelijnk oorzaak. De Takkeling, $8,221-222$.

Wyatt, R.D., Hamilton, P.B. \& Burmeister, H.R. (1975). Altered feathering of chicks caused by T-2 toxin. Poultry Science, 54, 1042-1045.

Young, R.J., Edwards, H.M. \& Gillis, M.B. (1958). Studies in zinc in poultry nutrition.

II. Zinc requirements and deficiency symptoms of chicks. Poultry Science, 37, 1100-1107. 
Figure 1. Loss of flight, tail feathers and coverts of a ten year old white-tailed sea eagle

(Haliaeetus albicilla) with pinching off syndrome (SA93).

Figure 2. Contorted rachis, ventral deposits of keratin (arrow) shortened calamus and feather length of secondaries of a white-tailed sea eagle with pinching off syndrome.

Figure 3. Normal primary of a feather-healthy white-tailed sea eagle (left) and altered Formatted: Indent: Left: 0 pt, First line: 0 pt, Line spacing: single

regrown primaries of a white-tailed sea eagle with pinching off syndrome (right).

Figure 4. Pathological keratinisation in a feather papilla of a white-tailed sea eagle with pinching off syndrome (1 Epithelium of the pulp; 2 Epithelium of the follicle; 3

Pathological keratinisation in the papilla).

Figure 5. Cross sections through the base of a developing feather with its follicle from a white-tailed sea eagle with pinching off syndrome. 5A: Early formation of a keratin layer from the epidermal collar of the feather (left) and the follicle wall (right) (scale bar: $5 \mu \mathrm{m}) .5 \mathrm{~B}$ : Transitional cells of the follicle wall connected by many desmosomes with cytokeratin filament bundles. Vacuole closely associated with an irregularly shaped nucleus (scale bar: $1 \mu \mathrm{m})$. Inset: Vesicle $(500 \mathrm{~nm}$ diameter) showing a trilaminar structure of its outer membrane (scale bar: $0.5 \mathrm{~nm}$ ). 
Table 1. Hatching year; body weight at the time of recovery, sex and origin (federal state) of clinically examined white-tailed sea eagles with pinching off syndrome

\begin{tabular}{lcccl}
\hline Bird & Hatching year & $\begin{array}{c}\text { Body weight } \\
{[\mathrm{kg}]}\end{array}$ & Sex & Federal state \\
\hline SA93 & 1993 & 4.8 & female & Saxony-Anhalt \\
SA01 & 2001 & 2.9 & male & Schleswig-Holstein \\
SA02 & 2002 & 3.9 & female & Brandenburg \\
SA03 & 2003 & 4.3 & female & Brandenburg \\
\hline
\end{tabular}


Table 2. Values of thyroxine $\left(T_{4}\right)$ before and six to eight hours after TSH application and the stimulation factors of the four white-tailed sea eagles with pinching off syndrome (POS) and one juvenile bird without feather abnormalities (1850)

\begin{tabular}{|c|c|c|c|c|c|}
\hline Bird & $\begin{array}{l}\text { Health } \\
\text { status }\end{array}$ & $\begin{array}{c}\mathrm{T}_{4} \text { basal level } \\
\text { [nmol/L] }\end{array}$ & $\begin{array}{c}\mathrm{T}_{4} \text { after stimulation } \\
{[\mathrm{nmol} / \mathrm{L}]}\end{array}$ & $\begin{array}{c}\text { Stimulation factor } \\
\left(\mathrm{T}_{4} \text { after } / \mathrm{T}_{4} \text { before } \mathrm{TSH} \text { application }\right)\end{array}$ & $\begin{array}{c}\text { Time } \\
\text { interval } \\
\text { [hours] }\end{array}$ \\
\hline SA93 & POS & 1.54 & 20.59 & 13.34 & 6 \\
\hline SA01 & POS & 2.32 & 27.93 & 12.04 & 8 \\
\hline SA02 & POS & 1.67 & 19.31 & 11.56 & 6 \\
\hline SA03 & POS & 4.63 & 22.52 & 4.86 & 6 \\
\hline 1850 & Healthy & 2.32 & 18.28 & 7.88 & 6 \\
\hline
\end{tabular}


Table 3. Histopathological results of altered organs in white-tailed sea eagles with pinching

Formatted: Font: Times New Roman, Italic off syndrome (- not detected, + slight degree, ++ moderate degree, +++ high degree)

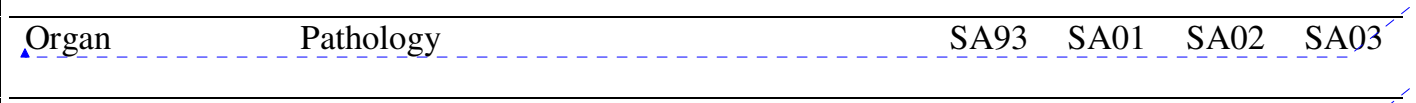

Heart

Degeneration of Purkinje fibres

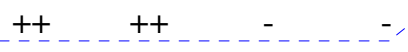

Lipofuscinosis of cardiac muscle cells

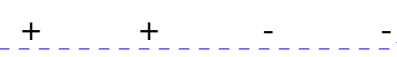

Liver

Iron deposition

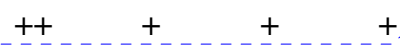

Formatted: Font: Times New

Formatted: Font: Times New

Formatted: Font: Times New

Formatted: Font: Times New

Formatted: Font: Times New

Formatted: Font: Times New

Formatted: Font: Times New

Kidney

Iron deposition

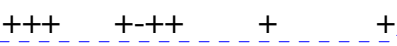

Formatted: Font: Times New

Formatted: Font: Times New

Cerebrum

Dilatation of the Virchow-Robin spaces

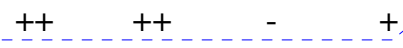

Swollen nuclei in endothelial cells of the ++ $+++_{-}$

Formatted: Font: Times New

Formatted: Font: Times New arterioles

Degeneration of neurons $+++{ }_{-+}^{+}$

Formatted: Font: Times New Deleted: nerve cells Deleted: nerve cells

Lipofuscinosis of neurons and glia cells Formatted: Font: Times New Formatted: Font: Times New Roman, Not Italic

Formatted: Font: Times New

Absence of colloid and follicle collapse $+++\ldots+{ }_{+}++$

Pancreas

Liposfuscin in the islet cells $++$ Formatted: Font: Times New Formatted: Font: Times New Deleted: F

Deleted: and colloid absence in follicles

Formatted: Font: Times New

Formatted: Font: Times New 
Table 4. Bacteria isolated from white-tailed sea eagles with pinching off syndrome

\begin{tabular}{lll}
\hline Bacterial isolate & Birds & Sample \\
\hline Brevibacterium epidermidis & SA02 & Feather follicle \\
Corynebacterium xerosis & SA01 & Feather pulp \\
Kocuria varians & SA03 & Soft tissue \\
Micrococcus sp. & SA01, SA02 & Feather pulp \\
Staphylococcus epidermidis & SA02 & Feather follicle \\
Staphylococcus hyicus & SA01 & Feather follicle, pulp \\
Staphylococcus simulans & SA03 & Soft tissue \\
Staphylococcus sp. & SA01 & Feather follicle, pulp \\
Acinetobacter calcoaceticus & SA01 & Feather follicle \\
Escherichia coli & SA01, SA93 & Feather follicle, pulp \\
\hline
\end{tabular}




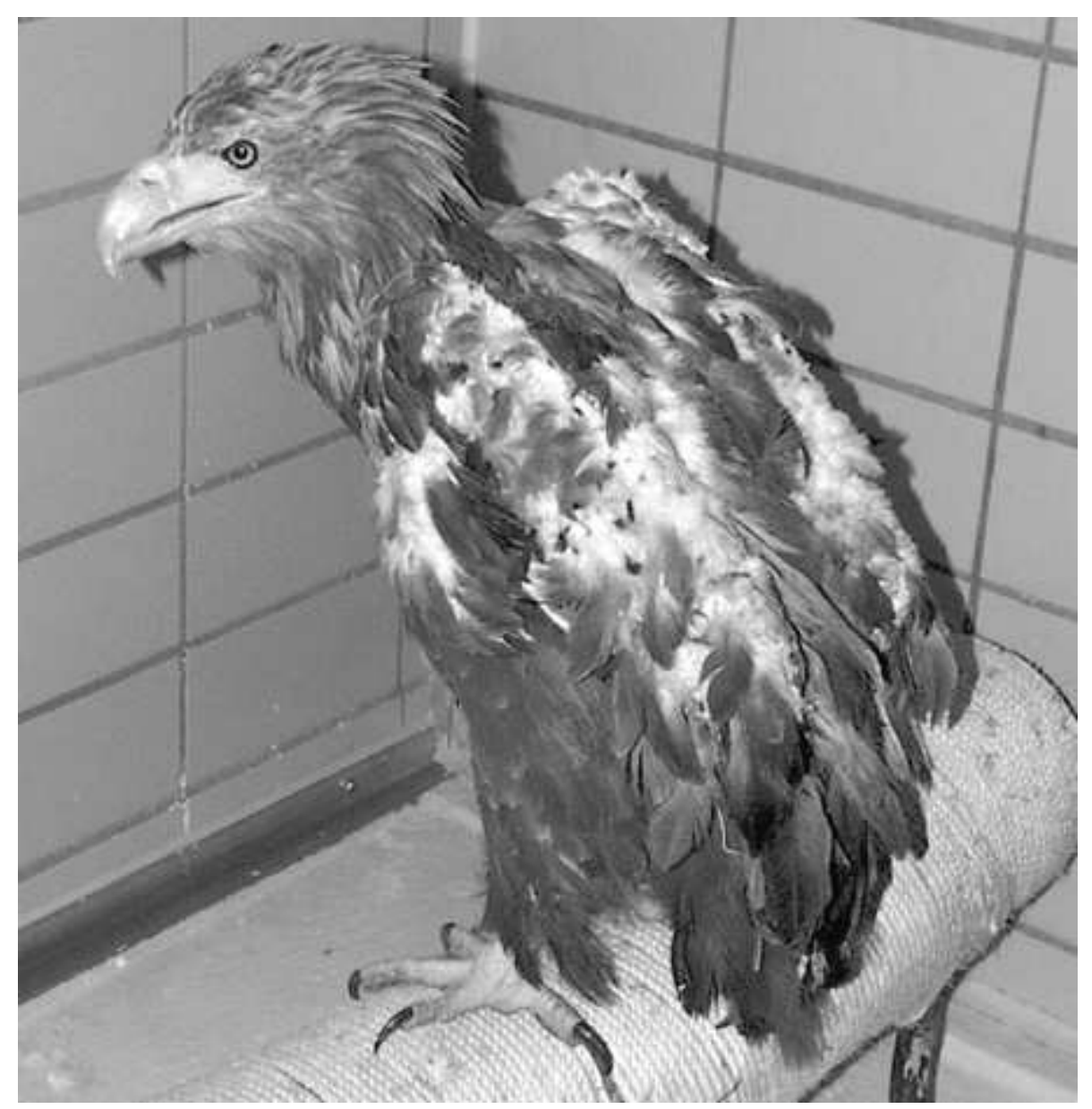

Figure 1. Loss of flight, tail feathers and coverts of a ten year old white-tailed sea eagle (Haliaeetus albicilla) with pinching off syndrome (SA93). $80 \times 82 \mathrm{~mm}(144 \times 144 \mathrm{DPI})$ 




Figure 2. Contorted rachis, ventral deposits of keratin (arrow) shortened calamus and feather length of secondaries of a white-tailed sea eagle with pinching off syndrome. $80 \times 111 \mathrm{~mm}(300 \times 300 \mathrm{DPI})$ 


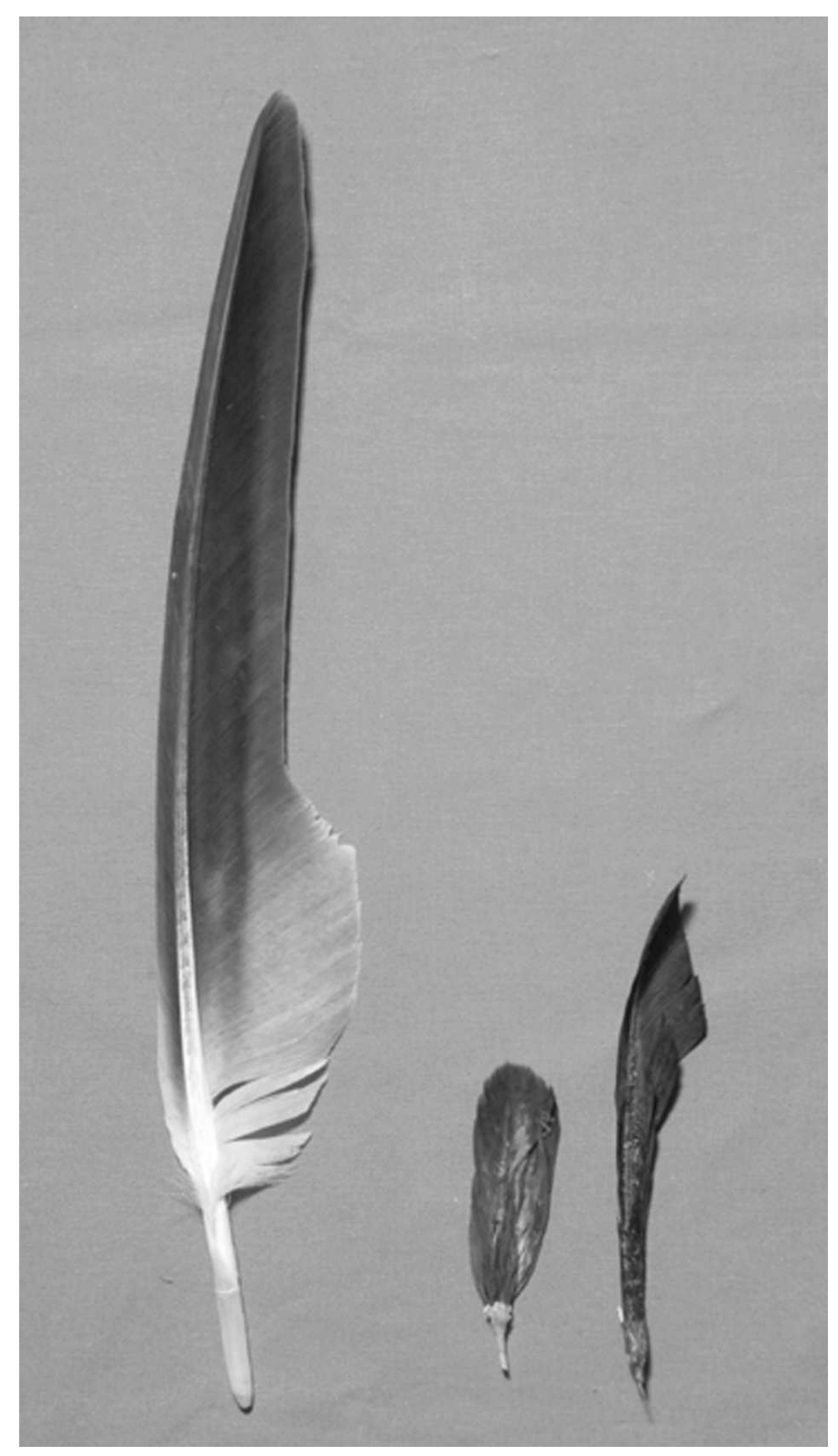

Figure 3. Normal primary of a feather-healthy white-tailed sea eagle (left) and altered regrown primaries of a white-tailed sea eagle with pinching off syndrome (right). $80 \times 141 \mathrm{~mm}(300 \times 300 \mathrm{DPI})$ 


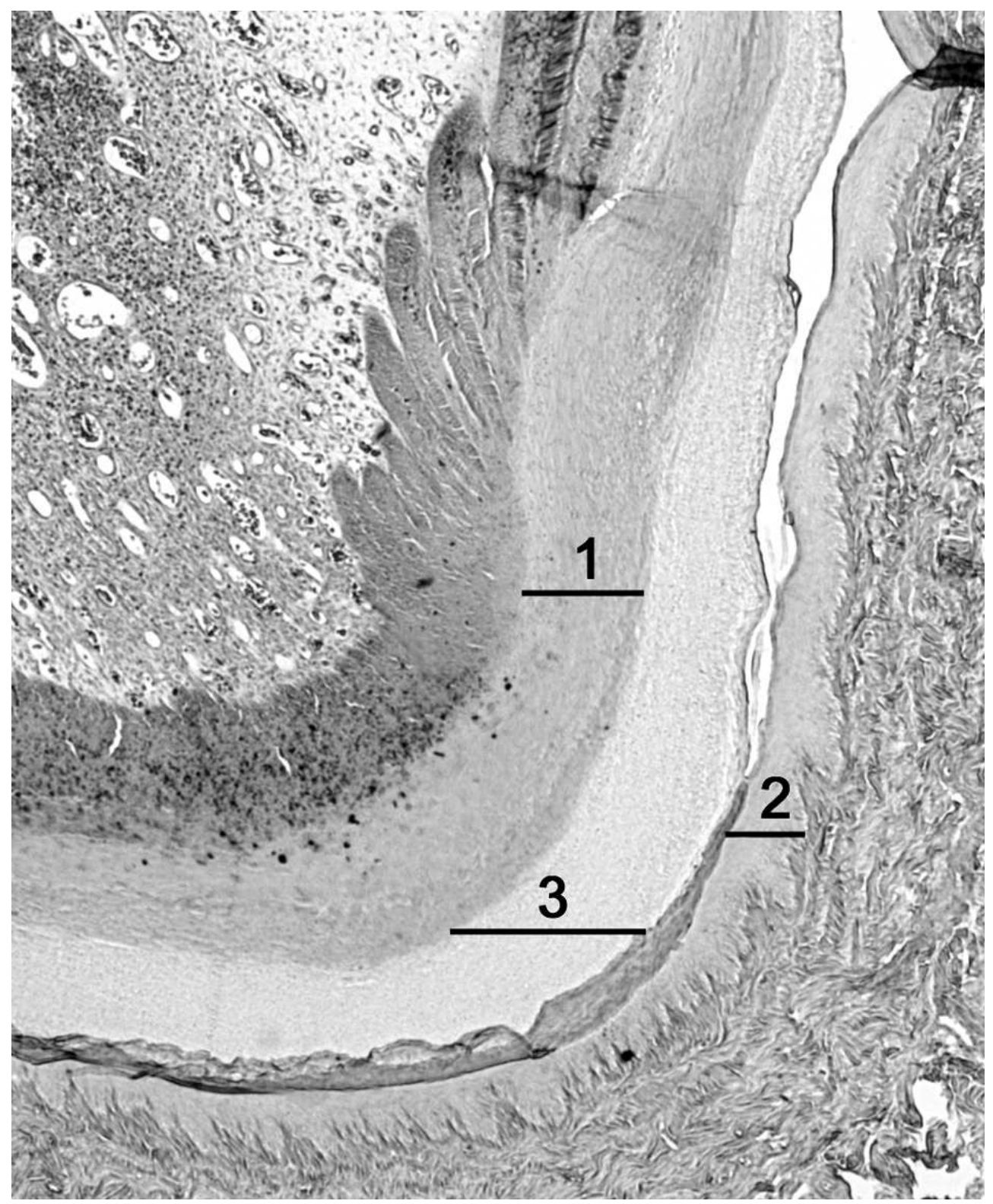

Figure 4. Pathologic keratinisation in a feather papilla of a white-tailed sea eagle with pinching off syndrome ( 1 Epithelium of the pulp; 2 Epithelium of the follicle; 3 Pathologic keratinisation in the papilla).

$80 \times 97 \mathrm{~mm}(300 \times 300 \mathrm{DPI})$ 


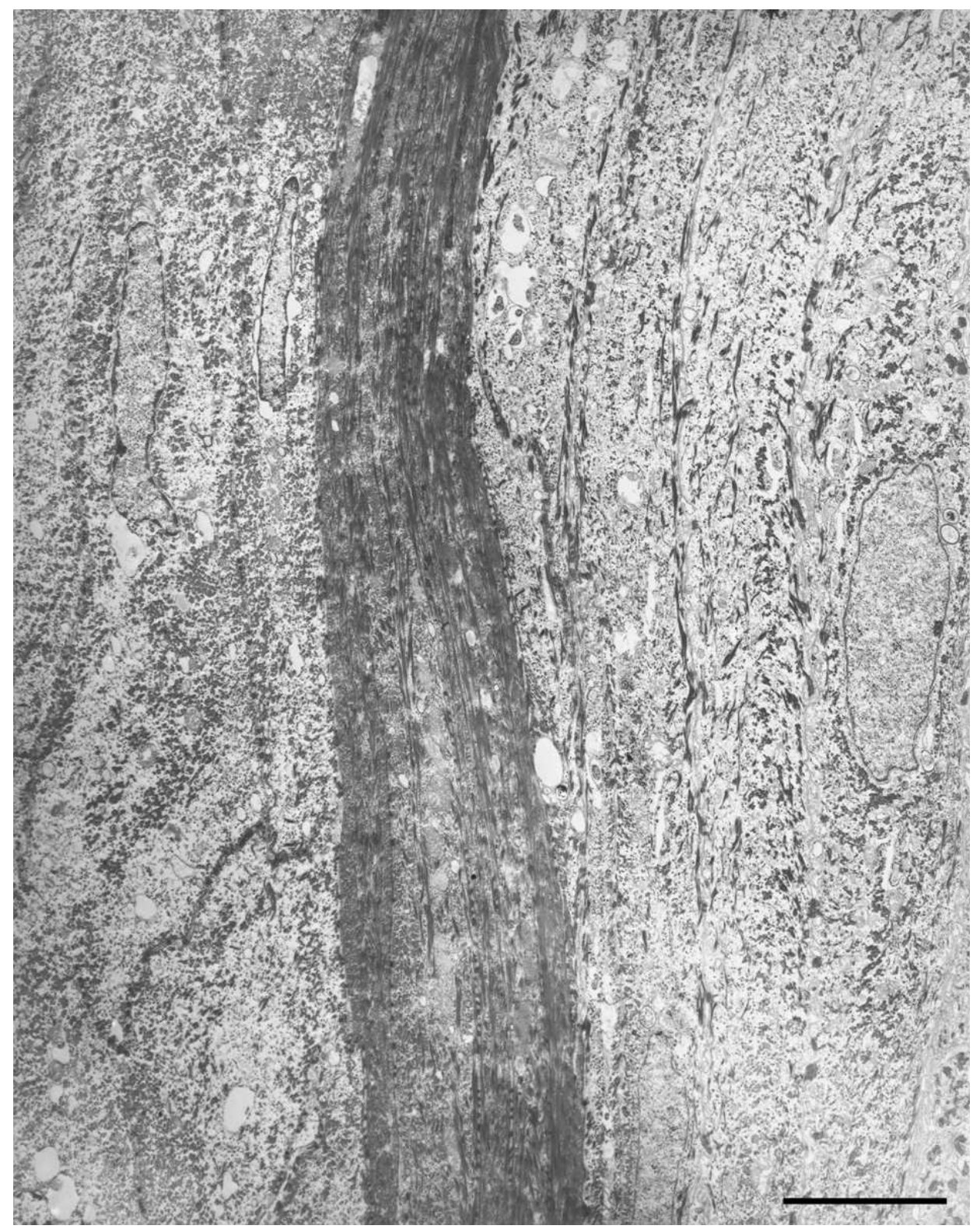

Figure 5. Cross sections through the base of a developing feather with its follicle from a whitetailed sea eagle with pinching off syndrome. 5A: Early formation of a keratin layer from the epidermal collar of the feather (left) and the follicle wall (right) (scale bar: $5 \mu \mathrm{m}$ ). $80 \times 101 \mathrm{~mm}(300 \times 300 \mathrm{DPI})$ 


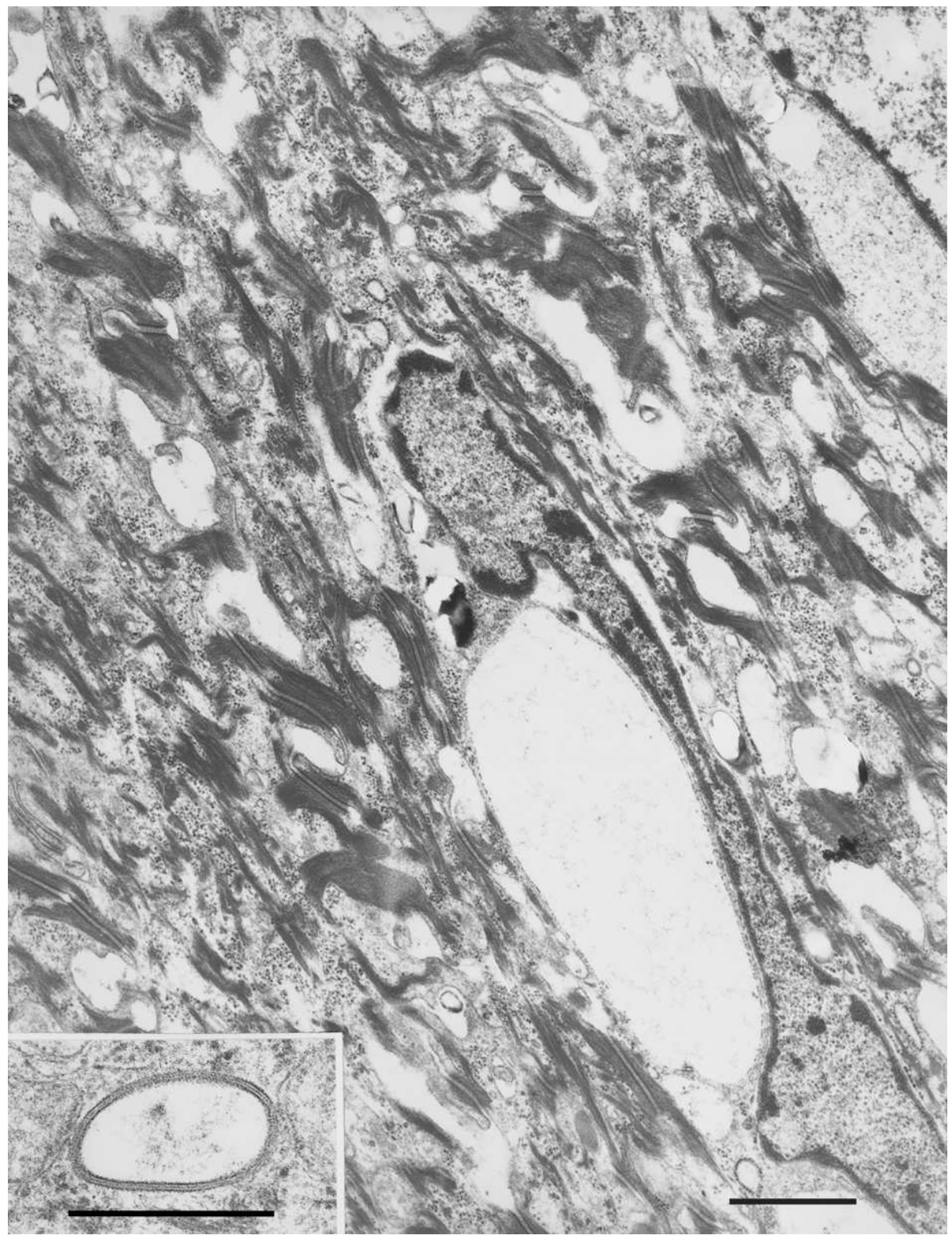

5B: Transitional cells of the follicle wall connected by many desmosomes with cytokeratin filament bundles. Vacuole closely associated with a irregularly shaped nucleus (scale bar: $1 \mu \mathrm{m})$. Inset: Vesicle (500 nm diameter) showing a trilaminar structure of its outer membrane (scale bar: 0.5 $\mathrm{nm})$.

$80 \times 104 \mathrm{~mm}(300 \times 300$ DPI $)$ 